p-ISSN: 0125-961X

Scientific Article

\title{
KEANEKARAGAMAN JENIS POHON DAN POTENSI SERAPAN KARBON TAMAN KEHATI BUMI PATRA, INDRAMAYU, JAWA BARAT
}

\author{
Tree diversity and potentials of carbon absorption of Bumi Patra Biodiversity Park, Indramayu, West Java
}

\author{
Nur Muhammad Heriyanto*, Hendra Gunawan \\ Pusat Penelitian dan Pengembangan Hutan, Badan Litbang Kehutanan dan Inovasi, Kementerian Lingkungan Hidup dan Kehutanan \\ Jl. Gunung Batu No. 5 Bogor, Jawa Barat
}

\section{Informasi Artikel \\ Diterima/Received : 14 September 2020 \\ Disetujui/Accepted : 30 November 2020 \\ Diterbitkan/Published : 1 Desember 2020 \\ *Koresponden E-mail : \\ nurmheriyanto88@yahoo.com}

DOI: https://doi.org/10.14203/bkr.v23i3.668

Cara mengutip

Heriyanto NM, Gunawan H. 2020.

Keanekaragaman jenis pohon dan potens serapan karbon taman kehati Bumi Patra,

Indramayu, Jawa Barat. Buletin Kebun Raya

23(3): 210-215. DOI:

https://doi.org/10.14203/bkr.v23i3.668

\section{Kontributor}

Kontributor Utama/Main author:

Nur Muhammad Heriyanto

Hendra Gunawan

Kontributor Anggota/Author member:

Keywords: biodiversity park, carbon absorption, greenhouse gases

Kata Kunci: gas rumah kaca, serapan karbon, taman kehati

\begin{abstract}
The Indonesian government is committed to reducing greenhouse gas emissions through deforestation prevention and planting trees. Planting trees in urban areas is carried out, among others, through the development of urban forests and biodiversity parks. Biodiversity parks have the function to increasing biodiversity in urban areas and absorb greenhouse gases. This study aims to determine the diversity of trees at Bumi Patra Bidoversity Park in Indramayu and their contribution to carbon absorption. Inventory and measurement of tree diameter and height were carried out by census method. Bumi Patra Biodiversity Park covered an area of 19.30 hectares with 38 plant species, a total of 1,889 trees, or an average density of 98 trees per hectare. The species diversity index $\left(\mathrm{H}^{\prime}\right)$ of vegetation in this biodiversity park is 3.16, with an evenness index (e) of 0.90 and a species richness index ${ }^{\circledR}$ of 5.36. Biomass and carbon content in Bumi Patra Biodiversity Park was 123.38 tons or equivalent to 61.69 tons C. The average biomass and carbon potential per hectare was 6.38 ton/ha or 3.20 tons $\mathrm{C} / \mathrm{ha}$. Potential biomass and carbon content were dominated by angsana (Pterocarpus indicus Willd) and mango (Mangifera indica L.) with $119.44 \mathrm{~kg}$ (59.72 tons $\mathrm{C}$ ) and 2.62 tons (1.31 tons C), respectively.
\end{abstract}

\begin{abstract}
Abstrak
Pemerintah Indonesia berkomitmen menurunkan emisi gas rumah kaca, antara lain melalui pencegahan deforestasi dan penanaman pohon. Penanaman pohon di perkotaan antara lain dilakukan melalui pembangunan hutan kota dan taman keanekaragaman hayati (taman kehati). Taman kehati memiliki fungsi meningkatkan keanekaragaman hayati di perkotaan dan menyerap gas rumah kaca. Penelitian ini bertujuan untuk mengetahui keanekaragaman jenis pohon di Taman Kehati Bumi Patra, dan kontribusinya terhadap serapan karbon. Inventarisasi dan pengukuran diameter dan tinggi pohon dilakukan dengan metode sensus. Hasil penelitian mencatat Taman Kehati Bumi Patra memiliki luas 19,30 hektare memiliki tanaman 38 jenis, berjumlah 1.889 pohon atau kerapatan rata-ratanya 98 pohon per hektar. Indeks keanekaragaman jenis $\left(H^{\prime}\right)$ vegetasi di taman kehati ini adalah 3,16, dengan indeks kemerataan jenis (e) 0,90 dan indeks kekayaan jenis ${ }^{\circledR} 5,36$. Biomassa dan kandungan karbon di Taman Kehati Bumi Patra sebesar 123,38 ton setara dengan 61,69 ton C. Rata-rata potensi biomassa dan karbon per hektar adalah 6,38 ton/ha atau 3,120 ton C/ha. Potensi biomassa dan kandungan karbon didominasi oleh angsana (Pterocarpus indicus Willd) dan mangga (Mangifera indica L.), masing-masing sebesar 119,44 ton $(59,72$ ton C) dan 2,62 ton (1,31 ton C).
\end{abstract}

\section{PENDAHULUAN}

Pemerintah Indonesia telah menargetkan penurunan emisi Gas Rumah Kaca (GRK) sebesar 26\% pada tahun 2020 (Samsoedin \& Waryono 2015). Penurunan emisi GRK dilakukan melalui pencegahan deforestasi dan degradasi hutan serta kegiatan penanaman pohon-pohon untuk menyerap GRK dari atmosfer, antara lain melalui program pembangunan hutan kota dan pembangunan ruang terbuka hijau (RTH) lainnya (Nasution \& Zahrah 2012; Imansari \& Parfi 2015). Pohon dan vegetasi melalui daun/batang mampu menyerap gas, komponen berbahaya dari udara dan mengeluarkan oksigen sehingga udara menjadi bersih (Al Fajar et al. 2014; Samsoedin \& Waryono 2015). RTH memiliki peranan penting dalam menyangga (biofiltering), mengendalikan (biocontroling), dan memperbaiki (bioengineering) kualitas lingkungan hidup wilayah 
perkotaan (Basworo 2011; Dinas Pertamanan Kota Bogor 2017).

Taman keanekaragaman hayati (taman kehati) adalah suatu kawasan pencadangan sumber daya alam hayati lokal di luar kawasan hutan yang mempunyai fungsi konservasi in situ dan/atau ex situ (Gunawan \& Sugiarti 2016). Berbeda dengan konsep ruang terbuka hijau sebelumnya yang masih tergantung pada beberapa jenis pohon (Samsoedin \& Waryono 2015), dan jenis-jenis tanaman estetika (Subarudi \& Samsoedin 2012), taman kehati lebih menekankan pada keanekaragaman jenis, status kelangkaan dan endemisitas atau keaslian dan lokalitas (Gunawan \& Sugiarti 2015a, 2016). Hal ini agar pohon-pohon yang ditanam dapat meningkatkan keanekaragaman hayati di perkotaan, sebagai antisipasi fenomena musnahnya keanekaragaman hayati global yang begitu cepat (Alvey 2006). Keanekaragaman hayati juga memiliki peran penting dalam menjaga fungsi ekosistem jangka panjang (Groombridge \& Jenkins 2002).

Pembangunan taman kehati bertujuan untuk menyelamatkan berbagai jenis tumbuhan asli atau lokal yang terancam punah (Gunawan \& Sugiarti 2015b). Taman kehati diaplikasikan di lingkungan industri, karena memiliki multi fungsi yaitu sebagai ruang terbuka hijau dan area konservasi flora dan fauna (Gunawan \& Sugiarti 2015a). Kota yang padat dengan bangunan memiliki daya dukung keanekaragaman hayatiyang lebih rendah dibanding dengan daerah yang masih alami. Banyak penelitian menunjukkan bahwa hilangnya habitat dan fragmentasi habitat alami telah mengurangi kekayaan taksa tumbuhan, burung, serangga, dan mamalia di pusat kota hingga kurang dari setengah yang ditemukan di daerah perdesaan (McKinney 2002).

Mempromosikan dan melestarikan keanekaragaman hayati di ruang terbuka hijau perkotaan merupakan salah satu cara memperlambat laju kepunahan keanekaragaman hayati (Alvey 2006). Sampai tahun 2016 tercatat sudah ada 78 taman kehati, 69 di antaranya dibangun oleh pemerintah daerah dan sembilan dibangun oleh swasta (IBSAP 2016). Sebanyak 29 taman kehati sudah ditetapkan oleh Gubernur atau Bupati di 29 kabupaten dari 13 provinsi dengan luas keseluruhan 1.863,55 hektar. Salah satu taman kehati yang telah ditetapkan adalah Taman Kehati Bumi Patra yang dibangun oleh PT. Pertamina RU VI Balongan, Indramayu, berdasarkan SK Bupati Indramayu No 660.1/Kep.64.A.21-BLH/2016. Taman Kehati Bumi Patra dibangun sejak tahun 2015, dan terus dikembangkan dengan penambahan luas dan jumlah jenis pohon yang dikonservasi. Sampai dengan tahun 2020 telah ditanam 33 jenis pohon asli dan introduksi di lahan seluas 19,30 hektar, di antaranya ada 11 varietas mangga yang menjadi ikon Kabupaten Indramayu (Gunawan \& Sugiarti 2020).
Karbondioksida penting untuk dihitung dan dipelajari dalam kaitannya dengan peranan taman kehati karena pohon berperan sebagai penyimpan karbondioksida $\left(\mathrm{CO}_{2}\right)$. Emisi $\mathrm{CO}_{2}$ di Indonesia pada tahun 2006 mencapai puncaknya yaitu 195 juta ton $\mathrm{CO}_{2}{ }^{-\mathrm{e}}$, dan tahun 2010 sebesar 74 juta ton $\mathrm{CO}_{2}^{-\mathrm{e}}$ (INCAS 2015). Menurut Purwanta (2010), emisi $\mathrm{CO}_{2}$ pada tahun 20012006 sebesar 827,06 juta ton $\mathrm{CO}_{2}$ per tahun berasal dari industri ( $6 \%$ dari seluruh sektor), yang banyak terdapat di perkotaan. Oleh karena itu, keberadaan pepohonan di lingkungan perkotaan harus dikelola dengan baik sebagai penyerap $\mathrm{CO}_{2}$. Pohon-pohon mengikat karbon melalui fotosintesis seiring dengan pertumbuhannya dan menyimpannya sebagai biomasa (McPherson et al. 1999; Nowak et al. 2013). Jumlah biomassa suatu daerah diperoleh dari produksi kepadatan biomassa dan jenis pohon (Dharmawan \& Samsoedin 2012).

Ruang terbuka hijau di kawasan perkotaan menjadi semakin penting karena urbanisasi terus meningkat di seluruh dunia (Yilmaz et al. 2008). Ruang terbuka hijau sering dirancang dengan tujuan untuk meningkatkan kualitas hidup di kota-kota yang tekanan sosialnya semakin parah (Yilmaz \& Irmak 2004). Pepohonan di perkotaan berpengaruh baik terhadap perubahan iklm, tetapi seringkali kurang mendapat perhatian karena jasa ekosistemnya kurang dipahami atau tidak dikuantifikasikan (Nowak et al. 2013). Kegiatan pendugaan biomassa dan kandungan karbon di hutan kota dan taman kehati perlu dilakukan karena potensi biomassa kumulatifnya yang besar dalam menyerap karbon. Apalagi hal tersebut juga merupakan mekanisme pembangunan bersih, yaitu mengurangi emisi $\mathrm{CO}_{2}$, dan mencegah kerusakan hutan untuk mengurangi pemanasan global (Lugina et al. 2011). Penelitian ini bertujuan untuk menghitung kontribusi Taman Kehati Bumi Patra PT. Pertamina RU VI Balongan di Indramayu, Jawa Barat, dalam menyerap dan menyimpan karbon serta meningkatkan keanekaragaman hayati di daerah perkotaan.

\section{METODE PENELITIAN}

\section{Waktu dan lokasi penelitian}

Penelitian ini dilakukan pada bulan Januari 2018 Februari 2020 di Taman Kehati Bumi Patra PT. Pertamina RU VI Balongan, Indramayu, Jawa Barat. Secara administratif taman kehati ini terletak di Desa Singajaya dan Karanganyar, Kecamatan Indramayu, Kabupaten Indramayu (Gambar 1). Secara geografis terletak di antara $108^{\circ} 20^{\prime} 9,6^{\prime \prime}$ BT dan $108^{\circ} 20^{\prime} 31,2^{\prime \prime}$ BT dan di antara $6^{\circ} 21^{\prime}$ 7,2" LS dan $6^{\circ} 21^{\prime} 48,0^{\prime \prime}$ LS. Taman Kehati Bumi Patra memiliki luas 19,30 hektare dan terbagi ke dalam Blok Mango Center-1 (2,30 ha), Blok Mango Center-2 (5,46 ha), 
Blok Tanaman Langka (6,23 ha), Blok Mangga Agrimania (3,35 ha) dan BlokTaman Rusa (1,96 ha).

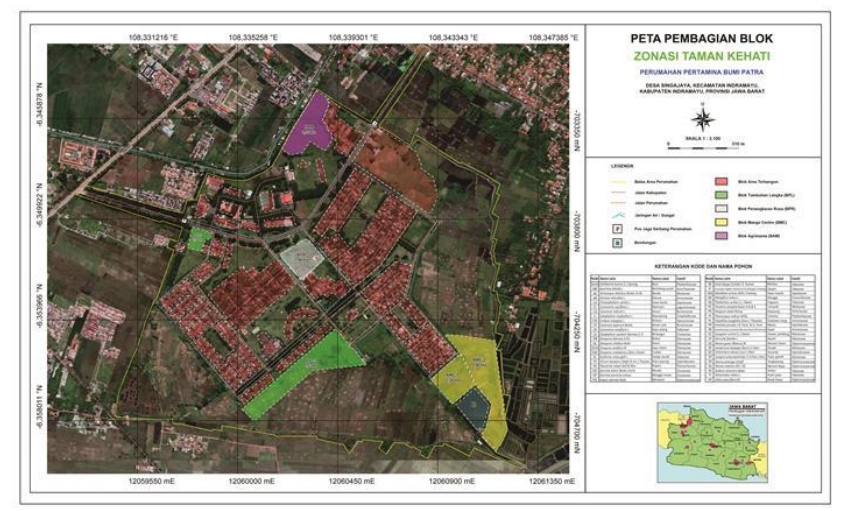

Gambar 1. Lokasi penelitian

\section{Pengumpulan data}

Inventarisasi pohon dilakukan secara sensus (100\%) untuk mengetahui jumlah dan jenis pohon yang terdapat di lokasi penelitian. Parameter yang diukur untuk penghitungan karbon yaitu diameter batang dan tinggi pohon (Heriyanto et al. 2019a). Diameter batang setinggi dada (diameter at breast height/DBH) diukur pada sekitar $130 \mathrm{~cm}$ dari atas permukaan tanah, menggunakan phi band. Tinggi pohon diukur menggunakan Hagloof Vertex II digital dengan kepekaan $10 \mathrm{~cm}$. Identifikasi jenis pohon dilakukan dengan mengambil sampel herbarium untuk diidentifikasi di Herbarium Puslitbang Hutan, Bogor. Data pertumbuhan vegetasi (diameter dan tinggi) dicatat. Pertumbuhan vegetasi merupakan selisih antara saat tumbuhan ditanam dengan waktu penelitian.

Kriteria vegetasi dan parameter yang digunakan mengikuti Kartawinata (2016) dan Heriyanto et al. (2019b). Pohon, yaitu tumbuhan berkayu dengan DBH $\geq 10$ $\mathrm{cm}$; . Belta, yaitu tumbuhan berkayu yang mempunyai tinggi $\geq 1,5 \mathrm{~m}$ dan $\mathrm{DBH}$ antara $2 \mathrm{~cm}$ sampai $<10 \mathrm{~cm}$. Untuk pohon dan belta, parameter yang diamati adalah jenis, diameter, dan tinggi. Semai, yaitu permudaan tumbuhan mulai dari kecambah sampai tinggi $<1,5 \mathrm{~m}$; parameter yang dicatat: jenis dan jumlah individu.

\section{Analisis data}

1. Keanekaragaman jenis

Data jenis vegetasi dianalisis untuk mendapatkan nilai indeks keanekaragaman jenis (diversity index) serta indeks kemerataan jenisnya (evenness index). Indeks keanekaragaman jenis dihitung dengan rumus dari Shannon H' (Ludwig \& Reynold 1988; Magurran 1988), yaitu:

$$
H^{\prime}=\sum p i \log p i_{, \operatorname{dimana}} p i=\frac{n i}{N}
$$

Keterangan: pi adalah perbandingan antara jumlah individu spesies ke-i dengan jumlah total individu. Logaritma yang digunakan adalah logaritma dasar 10 atau e. Rumus ini dapat diubah menjadi (Soegianto 1994) :

$$
H^{\prime}=\frac{\left(N \log N-\sum n i \log n i\right)}{N}
$$

Dengan klasifikasi sebagai berikut:

- $\mathrm{H}^{\prime}<1$ menunjukkan tingkat keanekaragaman jenis yang rendah

- $1<\mathrm{H}^{\prime}<3$ menunjukkan tingkat keanekaragaman jenis yang sedang

- $\mathrm{H}^{\prime}>3$ menunjukkan tingkat keanekaragaman jenis yang tinggi

Untuk mengetahui struktur komunitas maka dihitung nilai kemerataan antar jenis atau indeks evenness (e) dengan rumus sebagai berikut (Ludwig \& Reynold 1988; Odum 1994) :

$$
e=\frac{H^{\prime}}{\ln S}
$$

Keterangan: S adalah banyaknya jenis pada suatu tipe habitat yang diamati. Hasilnya diklasifikasikan menjadi:

- Komunitas stabil: 0,75< e $\leq 1$

- Komunitas labil: 0,5<e $\leq 0,75$

- Komunitas tertekan: $0<\mathrm{e} \leq 0,5$

Indeks kekayaan (R) dapat dihitung dengan menggunakan rumus yang diadopsi dari Margalef (1958) :

$$
\mathrm{R}=\frac{S-1}{\ln (N)}
$$

Keterangan: $\mathrm{R}$ indeks kekayaan jenis, $\mathrm{S}$ jumlah total jenis dalam suatu habitat, $\mathrm{N}$ jumlah total individu dalam suatu habitat. Hasilnya diklasifikasikan sebagai berikut:

- $\mathrm{R}<2,5$ menunjukkan tingkat kekayaan jenis yang rendah

- $2,5<\mathrm{R}<4$ menunjukkan tingkat kekayaan jenis yang sedang

- $\mathrm{R}>4$ menunjukkan tingkat kekayaan jenis yang tinggi

\section{Pendugaan karbon}

Analisis data dilakukan untuk menghitung volume (pohon \& belta) dan potensi penyerapan GRK menggunakan persamaan-persamaan berikut (Heriyanto et al. 2019a):

a. Volume pohon (V) dihitung dengan rumus:

$$
V=1 / 4 \pi \times D^{2} \times T \times f
$$

Dimana $\mathrm{V}$ adalah volume pohon $\left(\mathrm{m}^{3}\right)$, D adalah diameter batang $(m), T$ adalah tinggi $(m), f$ adalah angka bentuk $(0,6)$ dan $\pi=3,14$. 
b. Kandungan karbon tegakan (C), dihitung dengan menggunakan formula dari International Panel on Climate Change/IPCC GPG (2013):

$$
C=(\text { V. D. CF) }
$$

Keterangan: C adalah kandungan karbon, $\mathrm{V}$ adalah volume pohon, D adalah berat jenis kayu (Pustekolah 2013; ICRAF 2017) dan CF adalah fraksi karbon dari biomas (0.5).

\section{HASIL DAN PEMBAHASAN}

\section{Struktur dan komposisi}

Taman Kehati Bumi Patra terbagi ke dalam enam blok sesuai peruntukannya. Jumlah total tegakan tumbuhan (tingkat pohon, belta dan semai) di Taman Kehati Bumi Patra adalah 1.889 individu. Luas masingmasing blok dan jumlah tanaman di dalamnya disajikan pada Tabel 1. Umur tanaman sangat bervariasi, yaitu mulai dari 1, 2, 4, 5sampai 40 tahun. Kerapatan tumbuhan keseluruhan adalah 98 individu per hektare. Kerapatan tumbuhan tertinggi di Blok Tanaman Langka-2 dan terendah di Taman Rusa. Taman Rusa memiliki kerapatan pohon yang rendah, sebab area ini merupakan area terbuka untuk pertumbuhan rumput yang disediakan untuk pakan rusa.

Tabel 1. Luas blok dan jumlah tumbuhan di setiap blok Taman Kehati Bumi Patra

\begin{tabular}{llcccc}
\hline No & \multicolumn{1}{c}{ Blok } & $\begin{array}{c}\text { Luas } \\
\text { (ha) }\end{array}$ & $\begin{array}{c}\text { Jumlah } \\
\text { individu }\end{array}$ & $\begin{array}{c}\text { Umur } \\
\text { (tahun) }\end{array}$ & $\begin{array}{c}\text { Kerapatan } \\
\text { tumbuhan } \\
\text { (individu ha }\end{array}$ \\
\hline 1 & Mango Center-1 & 2,30 & 311 & 4 & 135 \\
2 & Mango Center-2 & 5,46 & 583 & 4 & 107 \\
3 & Tanaman Langka-1 & 5,53 & 155 & 5 & 28 \\
4 & Taman Rusa & 1,96 & 27 & 40 & 14 \\
5 & Tanaman Langka-2 & 0,70 & 229 & 1 & 327 \\
6 & Agrimania & 3,35 & 584 & 2 & 174 \\
\hline
\end{tabular}

\section{Keanekaragaman jenis ( $\left.\mathbf{H}^{\prime}\right)$}

Pada tahun 2018 Taman Kehati Bumi Patra memiliki tumbuhan koleksi sebanyak 18 jenis dengan jumlah 160 individu. Pada tahun 2020 jenis dan jumlah tumbuhan koleksi telah ditambah menjadi 38 jenis dengan 1.889 individu. Penambahan jenis dan jumlah tumbuhan tersebut menyebabkan meningkatnya nilai indeks keanekaragaman jenis $\left(H^{\prime}\right)$, dan indeks kekayaan jenis ${ }^{\circledR}$ sebagaimana disajikan pada Tabel 2. Kenaikan indeks keanekaragaman jenis disebabkan adanya penambahan jenis dengan jumlah bibit yang tersebar merata yang ditunjukkan oleh nilai indeks kemerataan jenis. Indeks keanekaragaman jenis dan indeks kekayaan jenis pohon di Taman Kehati Bumi Patra tergolong tinggi. Demikian juga nilai indeks kemerataan jenisnya tergolong stabil atau tinggi. Penelitian Auliandari et al. (2020) di beberapa RTH, keanekaragaman vegetasi $\left(H^{\prime}\right)$ yang menyusun hutan kota di Palembang beragam dari yang terendah hingga tertinggi yaitu 0,32 untuk Hutan Kota Bumi Perkemahan Gandus, Kawasan Kolam Retensi OPI $(0,93)$, Hutan Bandara Lanud Sri Mulyono Herlambang $(2,56)$, TWA Punti Kayu (3,01), Kawasan Stadion Jakabaring $(3,25)$ dan Hutan Bukit Siguntang $(3,29)$.

Tabel 2. Performa ekologi Taman Kehati Bumi Patra

\begin{tabular}{llrrrr}
\hline No. & \multicolumn{1}{c}{ Parameter } & $\mathbf{2 0 1 8}$ & Kategori & $\mathbf{2 0 2 0}$ & Kategori \\
\hline 1. & Jumlah jenis & 18 & - & 38 & - \\
2. & Jumlah individu & 160 & - & 1.889 & - \\
3. & Indeks keanekaragaman $\left(\mathrm{H}^{\prime}\right)$ & 2,12 & Sedang & 3,16 & Tinggi \\
4. & Indeks kemerataan $(\mathrm{e})$ & 0,73 & Labil & 0,90 & Stabil \\
5. & Indeks kekayaan Jenis $\left({ }^{\circledR}\right)$ & 3,35 & Sedang & 5,36 & Tinggi \\
\hline
\end{tabular}

Sebanyak 38 jenis tumbuhan (Lampiran 1) penyusun vegetasi Taman Kehati Bumi Patra berasal dari 18 suku dan 29 marga (Gambar 2). Suku Dipterocarpaceae memiliki jumlah jenis terbanyak yaitu lima jenis, diikuti oleh suku Ebenceae dan Fabaceae yang masing-masing memiliki empat jenis. Anonaceae, Clusiaceae, dan 
Sapotaceae masing-masing tiga jenis. Suku Sapindaceae, Phyllantaceae, Myrtaceae, dan Burseraceae masingmasing memiliki dua jenis. Suku lainnya hanya memiliki satu jenis. Suku Fabaceae, Dipterocarpaceae, dan Sapotaceae memiliki jumlah marga terbanyak, yaitu masing-masing tiga marga, diikuti oleh Sapindaceae, Phyllantaceae, dan Clusiaceae yang masing-masing terdiri atas dua marga. Sementara suku lainnya hanya memiliki satu marga.

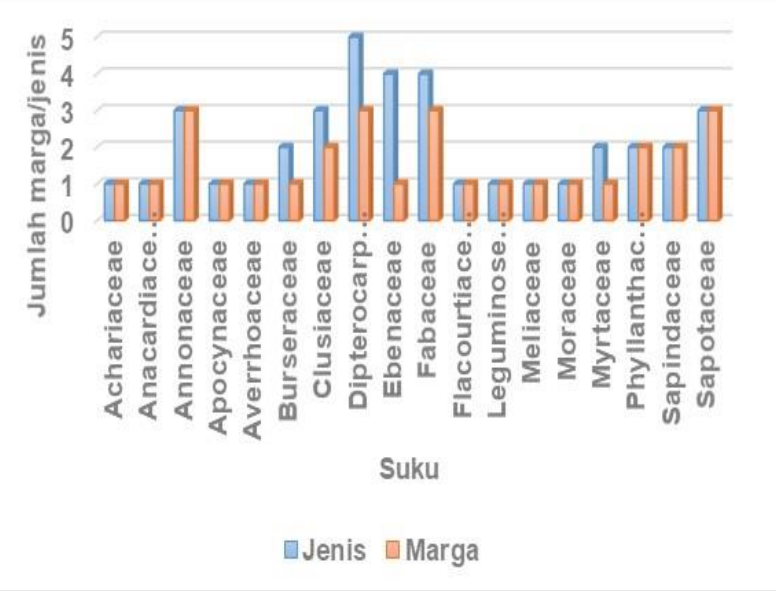

Gambar 2. Sebaran marga dan jenis di setiap suku
Lampiran 1 menyajikan jenis-jenis tumbuhan lokal yang keberadaannya di alam sudah sulit ditemukan, walaupun belum termasuk ke dalam Peraturan Pemerintah (KLHK) No. 16 tahun 2018 maupun CITES dan IUCN. Ada lima jenis yang termasuk langka lokal yaitu kupa/gowok (Syzygium polycephaloides (C.B.Rob.) Merr., kepel (Stelechocarpus burahol Hook. F. \& Thomson), kepayang/kluwak (Pangium edule Reinw.), gayam (Inocarpus fagifer (Parkinson \& Zollinger) Fosberg), dan nam-nam (Cynometra cauliflora L.). Populasi yang ditanam di RTH tersebut berdasarkan proporsi masingmasing jenis yaitu $6,3 \%, 4,2 \%, 7,9 \%$., $9 \%$, dan $10 \%$,

\section{Pendugaan karbon}

1. Pertumbuhan diameter dan tinggi

Tumbuhan yang dipelihara di semua blok Taman Kehati Bumi Patra umumnya mengalami pertumbuhan yang ditandai dengan bertambahnya diameter batang dan tinggi pohon. Hal ini tampak dari ukuran diamater dan tinggi pohon hasil pengukuran tahun 2020. Pertumbuhan diameter sangat bervariasi antar lokasi. Perbandingan diameter pohon di setiap blok (empat blok) dari tahun 2018 dan tahun 2020 disajikan pada Tabel 3.

Tabel 3. Pertambahan diameter dan tinggi tumbuhan pada periode 2018-2020, di Taman Kehati Bumi Patra

\begin{tabular}{|c|c|c|c|c|c|c|c|c|c|}
\hline \multirow{2}{*}{ No. } & \multirow{2}{*}{ Blok } & \multicolumn{2}{|c|}{ Diameter (cm) } & \multirow{2}{*}{$\begin{array}{l}\text { Pertum- } \\
\text { buhan } \\
\text { (cm) }\end{array}$} & \multirow{2}{*}{$\begin{array}{c}\text { Jumlah dan } \\
\text { simpangan } \\
\text { baku }\end{array}$} & \multicolumn{2}{|c|}{ Tinggi (m) } & \multirow{2}{*}{$\begin{array}{l}\text { Pertum- } \\
\text { buhan } \\
\text { (m) }\end{array}$} & \multirow{2}{*}{$\begin{array}{c}\text { Jumlah dan } \\
\text { simpangan } \\
\text { baku }\end{array}$} \\
\hline & & 2018 & 2020 & & & 2018 & 2020 & & \\
\hline 1. & Mango Center I & 4,06 & & 3,09 & $310(1,53)$ & 1,90 & & 0,62 & $310(0,52)$ \\
\hline 2. & Mango Center II & 3,01 & 9,23 & 5,42 & $564(3,93)$ & 1,10 & & 1,46 & $564(1,67)$ \\
\hline 3. & Taman Rusa & 62,11 & 76,06 & 13,95 & $26(18,32)$ & 19,31 & 24,23 & 4,93 & $26(3,02)$ \\
\hline 4. & Tanaman Langka & 3,38 & 7,21 & 3,83 & $152(3,4)$ & 1,64 & 3,22 & 1,58 & $152(1,91)$ \\
\hline
\end{tabular}

2. Kondisi fisik pohon

Jenis tumbuhan yang ditanam di lokasi penelitian pada umumnya merupakan jenis asli dari kawasan Asia Tenggara dan introduksi. Penanaman jenis-jenis asli di RTH ini menunjukkan bahwa perusahaan bertanggung jawab terhadap pengelolaan dan pemeliharaan taman, yaitu dengan memasukkan konsep konservasi ex situ melalui penanaman jenisjenis langka atau kurang dikenal, yang mewakili berbagai bio-region di Indonesia, sebagaimana telah diusulkan oleh banyak pihak (Suarja 2012; Samsoedin \& Waryono 2015; Andry et al. 2017). RTH ini juga menanam jenis-jenis tumbuhan yang memiliki potensi dalam menunjang pakan satwa yang terdapat di lokasi penelitian, seperti buni (Antidesma bunius (L.) Spreng) dan matoa (Pometia pinnata J.R. Forst. \& G. Forst) yang dimanfaatkan buahnya untuk pakan burung dan bajing, serta angsana (Pterocarpus indicus Willd.) sebagai tempat bersarang burung.
Kondisi seluruh tumbuhan yang diamati di lokasi RTH tersebut, pada umumnya terawat dengan baik. Jenis tumbuhan terbanyak ditanam pada tahun 2015 yaitu mangga (Mangifera indica L.), sebanyak 894 batang, bintaro (Cerbera manghas L.) 48 batang, kepuh (Sterculia foetida L.) 35 batang. Pada tahun 1979, RTH ini ditanami angsana (Pterocarpus indicus Willd) sebanyak 26 batang (Tabel 4). 
Tabel 4. Kisaran diameter empat jenis tumbuhan terbanyak di Taman Kehati Bumi Patra Pertamina RU VI Balongan

\begin{tabular}{llccccc}
\hline No & $\begin{array}{c}\text { Jenis } \\
\text { tumbuhan }\end{array}$ & $\begin{array}{c}\text { Diameter } \\
\text { minimum } \\
(\mathbf{c m})\end{array}$ & $\begin{array}{c}\text { Diameter } \\
\text { maksimum }(\mathbf{c m})\end{array}$ & $\begin{array}{c}\text { Diameter } \\
\text { rata-rata } \\
(\mathbf{c m})\end{array}$ & $\begin{array}{c}\text { Simpangan } \\
\text { baku }\end{array}$ & $\begin{array}{c}\text { Jumlah } \\
\text { pohon }\end{array}$ \\
\hline 1 & Mangga & 2 & 15 & 7,12 & 1,73 & 894 \\
2 & Bintaro & 3,1 & 13,1 & 6,47 & 2,27 & 48 \\
3 & Kepuh & 2,6 & 16,5 & 9,20 & 3,93 & 35 \\
4 & Angsana & 44,30 & 87,57 & 69,80 & 17,64 & 26 \\
\hline
\end{tabular}

Hasil pengukuran tinggi tumbuhan (Table 5) menunjukkan bahwa tinggi rata-rata tumbuhan yang terdapat di Taman Kehati Bumi Patra Pertamina RU VI Balongan bervariasi. Tumbuhan yang paling tinggi adalah angsana, yaitu $29,7 \mathrm{~m}$, sedangkan tumbuhan yang paling rendah adalah kepuh, sebesar $1,80 \mathrm{~m}$.

Jenis-jenis tumbuhan yang ditanam di area Taman Kehati Bumi Patra diutamakan adalah jenis lokal dan jenis asli Indonesia yang mulai langka dan sesuai dengan kondisi tanah dan iklim di daerah Indramayu. Pemilihan jenis tersebut telah sesuai dengan kriteria jenis untuk taman kehati (Gunawan \& Sugiarti 2016) dan sesuai dengan kriteria pembangunan hutan kota (Mulyana 2013; Samsoedin \& Waryono 2015).

Tabel 5. Kisaran tinggi empat jenis tumbuhan tertinggi di Taman Kehati Bumi Patra Pertamina RU VI Balongan

\begin{tabular}{llccccc}
\hline No & $\begin{array}{c}\text { Jenis } \\
\text { tumbuhan }\end{array}$ & $\begin{array}{c}\text { Tinggi } \\
\text { minimum }(\mathbf{m})\end{array}$ & $\begin{array}{c}\text { Tinggi } \\
\text { maksimum } \\
(\mathbf{m})\end{array}$ & $\begin{array}{c}\text { Tinggi } \\
\text { rata-rata/ } \\
(\mathbf{m})\end{array}$ & $\begin{array}{c}\text { Simpangan } \\
\text { baku }\end{array}$ & $\begin{array}{c}\text { Jumlah } \\
\text { tumbuhan }\end{array}$ \\
\hline 1 & Mangga & 1,95 & 6,1 & 2,59 & 0,50 & 894 \\
2 & Bintaro & 1,90 & 3,6 & 2,26 & 0,44 & 48 \\
3 & Kepuh & 1,80 & 6,5 & 4,87 & 1,83 & 35 \\
4 & Angsana & 16,4 & 29,7 & 22,05 & 2,66 & 26 \\
\hline
\end{tabular}

\section{Struktur tegakan}

Struktur tegakan adalah sebaran individu tumbuhan dalam lapisan tajuk dan dapat diartikan sebagai sebaran tumbuhan per satuan luas dalam berbagai kelas diameter (Siregar \& Heriyanto 2010; Wardani \& Heriyanto 2015). Sebaran kelas diameter tingkat belta dan tingkat pohon di lokasi penelitian menunjukkan jumlah individu yang semakin bertambah dari kelas diameter kecil (diameter $2-<6$ $\mathrm{cm})$ ke kelas diameter berikutnya $(6-<10 \mathrm{~cm})$ dan menurun di kelas diameter besar $\geq 10 \mathrm{~cm}$ kecuali di blok Taman Rusa, Agrimania dan Tanaman Langka-1 (Gambar 5). Jenis tumbuhan di lokasi penelitian didominasi oleh mangga (Mangifera indica L.) dan angsana (Pterocarpus indicus Willd.) (Gambar 5).

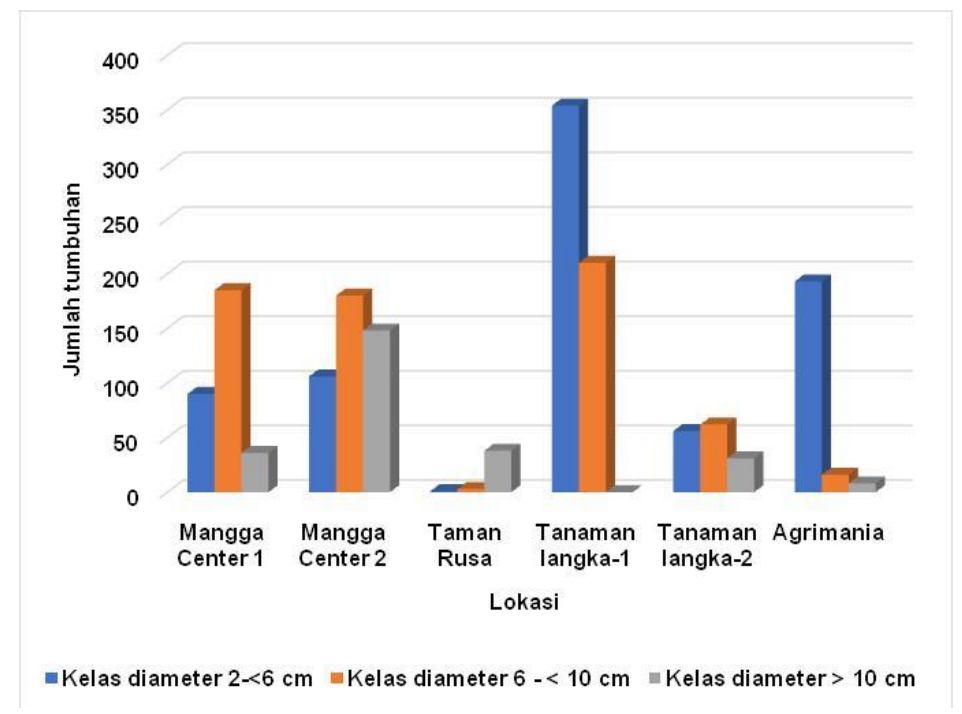

Gambar 5. Sebaran kelas diameter tingkat belta dan pohon di Taman Kehati Bumi Patra 


\section{Kandungan karbon}

Perhitungan potensi karbon dilakukan dengan menggunakan rumus persamaan seperti tertera pada metode penelitian. Data diameter dan tinggi dihasilkan dari data primer pengukuran, sedangkan data berat jenis kayu berasal dari Pustekolah (2013) dan ICRAF (2017). Pada Tabel 6, terlihat bahwa pohon yang menghasilkan karbon paling signifikan besar adalah jenis pohon angsana, yaitu sebesar 59.721,97 kg C dengan jumlah pohon sebanyak 26 pohon, diikuti oleh mangga sebanyak
790,79 kg C yang dihasilkan dari 310 pohon. Kandungan karbon suatu jenis pohon sangat tergantung dari kerapatan, umur dan dimensi (diameter dan tinggi) serta berat jenis kayu (Samsoedin et al., 2014).

Pertumbuhan atau riap tegakan pohon selama dua tahun (2018-2020) di Taman Kehati Bumi Patra sebesar 601,91 kg C di Blok Mango Center 1, 11.553,66 kg C di Blok Taman Rusa, dan 508,33 kg C di Blok Tanaman Langka.

Tabel 6. Perkiraan potensi karbon Taman Kehati Bumi Patra

\begin{tabular}{|c|c|c|c|c|c|c|}
\hline No. & Lokasi, jenis dan tahun tanam & Jumlah & $\begin{array}{c}\text { Biomassa } \\
\text { rata-rata } \\
(\mathrm{kg})\end{array}$ & $\begin{array}{c}\text { Biomassa } \\
\text { total } \\
(\mathrm{kg})\end{array}$ & $\begin{array}{c}\text { Kandungan } \\
\text { karbon } \\
(\text { kg C) }\end{array}$ & $\begin{array}{c}\text { Kandungan } \\
\mathrm{CO}_{2} \\
(\mathrm{~kg})\end{array}$ \\
\hline \multirow[t]{5}{*}{ a. } & Blok Mangga Center 1 & & & & & \\
\hline & Mangga (Mangifera indica L.) (2015) & & & & & \\
\hline & Pengukuran 2018 & 310 & 1,22 & 377,76 & 188,88 & 693,19 \\
\hline & Pengukuran 2020 & 310 & 5,10 & $1.581,59$ & 790,79 & $2.902,22$ \\
\hline & Pertumbuhan & - & 3,88 & $1.203,82$ & 601,91 & $2.209,01$ \\
\hline \multirow[t]{5}{*}{ b } & Blok Taman Rusa & & & & & \\
\hline & Angsana (Pterocarpus indicus Willd.) (1979) & & & & & \\
\hline & Pengukuran 2018 & 26 & $3.705,25$ & $96.336,62$ & $48.168,31$ & $176.777,70$ \\
\hline & Pengukuran 2020 & 26 & $4.593,99$ & $119.443,95$ & $59.721,97$ & $219.179,65$ \\
\hline & Pertumbuhan & - & 888,74 & $23.107,32$ & $11.553,66$ & $42.401,93$ \\
\hline \multirow[t]{5}{*}{ c } & Blok Agrimania & & & & & \\
\hline & Mangga (Mangifera indica L.) (2015) & & & & & \\
\hline & Pengukuran 2018 & - & - & - & - & - \\
\hline & Pengukuran 2020 & 564 & 1,78 & $1.037,28$ & 518,64 & $1.903,41$ \\
\hline & Pertumbuhan & - & - & - & - & - \\
\hline \multirow[t]{5}{*}{ d } & Blok Tanaman Langka & & & & & \\
\hline & 25 jenis pohon (2015) & & & & & \\
\hline & Pengukuran 2018 & 152 & 1,96 & 298,59 & 148,29 & 547,91 \\
\hline & Pengukuran 2020 & 152 & 8,65 & $1.315,27$ & 657,63 & $2.413,52$ \\
\hline & Pertumbuhan & - & 6,69 & $1.016,67$ & 508,33 & $1.865,59$ \\
\hline
\end{tabular}

Dari jumlah 1.889 batang tumbuhan yang ditanam di Taman Kehati Bumi Patra, 1.072 batang merupakan tingkat pohon dan belta. Total kandungan karbon di lokasi ini sebesar $61.689,03 \mathrm{~kg}$ C. Potensi biomassa dan karbon adalah $6.382,65 \mathrm{~kg} / \mathrm{ha}$ atau $3.196,32 \mathrm{~kg} \mathrm{C} / \mathrm{ha}$. Potensi ini masih akan meningkat karena pada umumnya jenis pohon yang ada di Taman Kehati Bumi Patra masih dalam pertumbuhan dan saat ini rata-rata berumur 5 tahun atau kurang, serta masih banyak pohon yang baru ditanam atau berumur kurang dari 1 tahun. Penelitian Heriyanto \& Samsoedin (2019) di RTH Toyota Sunter, Jakarta, dan RTH Karawang, Jawa Barat, dengan luas masing-masing 2,7 ha dan 36 ha, jumlah jenis 53 dan 32, rata-rata umur tegakan 5 tahun dengan jenis dominan yaitu mahoni, sengon buto, mangium, kayu putih, dan trembesi. Jumlah pohon yang ditanam di RTH Sunter sebanyak 987 batang (kerapatan 370 batang/ha) dan di RTH Karawang ada 2.941 batang (kerapatan 82 batang/ha). Total kandungan karbon di RTH Sunter sebesar 69,18 ton C (25,2 ton C/ha) dan di RTH Karawang sebesar 115,98 ton C (3,23 ton C/ha).
Tegakan tumbuhan tingkat belta mempunyai potensi besar dalam menyerap dan mengurangi kadar $\mathrm{CO}_{2}$ di udara. Hal ini karena pohon muda proses pertumbuhannya relatif lebih cepat dibandingkan dengan pohon yang sudah tua (Dharmawan 2013). Dalam pertumbuhan terjadi proses fotosintesis yang melibatkan $\mathrm{CO}_{2}$ dan air, yang diubah menjadi kabohidrat. Selanjutnya melalui proses metabolisme karbohidrat diubah menjadi lipid, asam nukleat, dan protein yang akan diubah menjadi organ tumbuhan (Widhi \& Murti 2014).

\section{KESIMPULAN DAN SARAN}

Taman Kehati Bumi Patra yang meliputi area seluas 19,30 hektar memiliki tanaman kolekis sebanyak, 1.889 individu yang tercakup dalam 38 jenis. Indeks keanekaragaman jenis $\mathrm{H}^{\prime}$ adalah 3,16 , dengan indeks kemerataan jenis $\mathrm{e}=0,90$ dan indeks kekayaan jenis $\AA=$ 5,36 . Indeks keanekaragaman dan kekayaan jenis tergolong tinggi dan komunitas vegetasinya termasuk 
stabil. Biomassa dan kandungan karbon di Taman Kehati Bumi Patra sebesar 123,38 ton dan 61,69 ton C, secara berturut-turut, atau potensi biomassa dan karbon per hektare adalah 6,38 ton/ha dan 3,20 ton C/ha. Perlu dilakukan penambahan jenis-jenis langka lokal ditanam di RTH/Taman Kehati tersebut.

\section{UCAPAN TERIMA KASIH}

Penulis menyampaikan terima kasih kepada segenap pihak yang telah memungkinkan pelaksanaan penelitian. Secara khusus terima kasih disampaikan kepada: General Manager PT Pertamina (Persero) RU VI Balongan; Direktur Operasi \& Pemasaran PT Pertamina Training and Consulting; Manager HSE PT Pertamina (Persero) RU VI Balongan; Section Enviro PT Pertamina (Persero) RU VI Balongan; Section CSR PT Pertamina (Persero) RU VI Balongan; Bapak Nana Kanan, PT Pertamina (Persero) RU VI Balongan; Bapak Aditya L Prabowo, PT Pertamina (Persero) RU VI Balongan; Bapak Rizky Firdaus Azhary (Pertamina Training and Consulting); Ridza Wikramasurya (Pertamina Training and Consulting); Direktur Koperasi Patra Wiralodra; Bapak Andi, Koperasi Patra Wiralodra; Ketua Kelompok Tani Wong Tanggul Ceblok (WTC) dan anggota; Pimpinan dan jajaran security Perumahan Bumi Patra; Bapak Makrus (Kelompok Pantai Lestari) dan Bapak H. Tasmin; Tim survei monitoring keanekaragaman hayati Taman Kehati Bumi Patra.

\section{DAFTAR PUSTAKA}

Al Fajar DD, La Sina, Rika E. 2014. Fungsi hutan kota dalam mengurangi pencemaran udara di kota Samarinda. Jurnal Beraja Niti 3(9): 1-12.

Alvey AA. 2006. Promoting and preserving biodiversity in the urban forest. Urban Forestry \& Urban Greening 5(4): 195-201. https://doi.org/10.1016/j.ufug. 2006. 09.003

Andry S, Triana D, Rivananda, Iswoyo H. 2017. Potensi pengembangan kawasan $\mathrm{MOI}$ sebagai RTH hutan kota dan kawasan agroeduwisata perkotaan. Hasanuddin Student Journal 1(1): 22-33.

Auliandari L, Lensari D, Angraini E. 2020. Keanekaragaman vegetasi di hutan kota sebagai salah satu ruang terbuka hijau publik Kota Palembang. Jurnal Biosains 6 (1): 1-10. DOI: https://doi.org/ 10.24114/jbio.v6i1.14523.

Basworo E. 2011. Perluasan RTH DKI Jakarta tanpa biaya pembebasan lahan. Dinas Pertamanan dan Pemakaman, Jakarta.

Dharmawan IWS, Samsoedin I. 2012. Dinamika potensi biomassa karbon pada landskap hutan bekas tebangan di Hutan Penelitian Malinau. Jurnal
Penelitian Sosial dan Ekonomi Kehutanan 9(1): 1220.

Dharmawan IWS. 2013. Persamaan alometrik dan cadangan karbon vegetasi pada hutan gambut primer dan bekas terbakar. Jurnal Penelitian Hutan dan Konservasi Alam 10 (2): 175-191.

Dinas Pertamanan Kota Bogor. 2017. Pengamatan taman dan pembuatan rancangan penataan taman sekota Bogor. PT. Beutari Nusakreasi, Bogor.

Groombridge B, Jenkins MD. 2002. World Atlas of Biodiversity: Earth's Living Resources in the 21st Century. University of California Press, Berkeley, CA.

Gunawan H, Sugiarti. 2015. Pelestarian keanekaragaman hayati ex situ melalui pembangunan Taman Kehati oleh sektor swasta: Lesson learned dari Group Aqua Danone Indonesia. Prosiding Seminar Nasional Masyarakat Biodiversiti Indonesia 1(3): 565-573. DOI: 10.13057/psnmbi/m010332.

Gunawan H, Sugiarti. 2015a. Keanekaragaman fauna taman kehati Mekarsari, Sukabumi, Jawa Barat. Prosiding Seminar Nasional Masyarakat Biodiversiti Indonesia 1(8): 1821-1827.

Gunawan H, Sugiarti. 2015b. Konservasi ex situ jenis-jenis pohon hutan pegunungan Jawa di Taman Kehati Babakan Pari, Sukabumi, Jawa Barat. Prosiding Seminar Nasional Masyarakat Biodiversiti Indonesia 1(6): 1364-1369.

Gunawan H, Sugiarti. 2016. Membangun Taman, Melestarikan Keanekaragaman: Manual Pembangunan Taman Keanekaragaman Hayati. Forda Press. Bogor.

Gunawan H, Sugiarti. 2020. Final Report Revitalisasi Taman Kehati dan Monitoring Penangkaran Rusa PT Pertamina (Persero) RU VI Balongan, Kabupaten Indramayu. PT. Pertamina (Persero) RU VI Balongan. Indramayu. Tidak diterbitkan.

Heriyanto NM, Samsoedin I Bismark M. 2019a. Keanekaragaman flora dan fauna di kawasan hutan Bukit Datuk Dumai Provinsi Riau. Jurnal Sylva Lestari, 7(1): 82-94.

Heriyanto NM, Samsoedin I, Kartawinata K. 2019b. Tree species diversity, structural characteristics and carbon stock in a one-hectare plot of the protection forest area in West Lampung Regency, Indonesia. Reinwardtia 18(1): 1-18.

Heriyanto NM, Samsoedin I. 2019. Struktur Tegakan dan Stok Karbon di Ruang Terbuka Hijau Perkotaan. Buletin Kebun Raya 22(2): 143-150.

IBSAP. 2016. Indonesian Biodiversity Strategy and Action Plant 2015-2020. Kementerian Perencanaan Pembangunan Nasional/BAPPENAS. Jakarta 
Imansari N, Parfi K. 2015. Penyediaan hutan kota dan taman kota sebagai ruang terbuka hijau (RTH) publik menurut preferensi masyarakat di kawasan pusat kota Tangerang. Ruang 1(3):101-110.

Indonesia National Carbon Accounting System [INCAS]. 2015. Indonesia luncurkan alat baru hadapi perubahan iklim. Program REDD-I. Hutan dan perubahan iklim di Indonesia. Kementerian Lingkungan Hidup dan Kehutanan Indonesia.

International Panel on Climate Change [IPCC]. 2013. Climate change 2013 the physical basis working group I contribution to the fifth assessment report of the IPCC. Switzerland.

International Center Research in Agroforestry/ICRAF. 2017. Database, wood density. ICRAF. Bogor. www.worldagroforestry.org. (diakses tanggal 18 Mei 2020).

Magurran AE. 1988. Ecological Diversity and Its Measurement. Croom Helm. London.

Margalef R. 1958. Information Theory in Ecology. General Systems 3: 36-71.

McKinney ML, 2002. Urbanization, biodiversity, and conservation. BioScience 52: 883-890.

McPherson E, Gregory, Simpson, James R. 1999. Carbon dioxide reduction through urban forestry: Guidelines for professional and volunteer tree planters. Gen. Tech. Rep. PSWGTR-171. Albany, CA: Pacific Southwest Research Station, Forest Service, U.S. Department of Agriculture; $237 \mathrm{p}$. http://www.psw.fs.fed.us/techpub. html

Mulyana S. 2013. Kajian jenis pohon potensial untuk hutan kota di Bandung, Jawa Barat. Jurnal Analisis Kebijakan Kehutanan 10(1): 58-71.

Nasution AD, Zahrah W. 2012. "Public open space's contribution to quality of life: does privatisation matters?". Asian Journal of Environment Behaviour Studies. 3(9): 59-74.

Nowak DJ, Greenfield EJ, Hoehn RE, Lapoint E. 2013. Carbon storage and sequestration by trees in urban and community areas of the United States. Environmental Pollution 178 (2013): 229-236.

Odum EP. 1994. Fundamentals of Ecology, Third Edition. T. Samingan (terj.). Gadjah Mada University Press, Yogyakarta.

Kartawinata K. 2016. Diversitas ekosistem alami Indonesia. Yayasan Pustaka Obor Indonesia, Jakarta.

Ludwig JA, Reynold JF. 1988. Statistical ecology: a primer on methods and computing. John Wiley \& Sons, New York.

Lugina M, Ginoga KL, Wibowo A, Bainnaura A, Partiani T. 2011. Prosedur Operasi Standar (SOP) untuk pengukuran stok karbon di kawasan konservasi.
Pusat Penelitian dan Pengembangan Perubahan Iklim dan Kebijakan. Badan Penelitian dan Pengembangan Kehutanan, Kementerian Kehutanan, Indonesia. Kerjasama dengan International Tropical Timber Organization (ITTO).

Purwanta W. 2010. Penghitungan emisi karbon dari lima sektor pembangunan berdasar metode IPCC dengan verifikasi faktor emisi dan data aktivitas lokal. Jurnal Teknologi Lingkungan 11(1): 71-77.

Pustekolah (Pusat Penelitian dan Pengembangan Keteknikan Kehutanan dan Pengolahan Hasil Hutan). 2013. Atlas kayu Indonesia jilid 4. Badan Penelitian dan Pengembangan Kehutanan, Departemen Kehutanan, Bogor.

Samsoedin I, Heriyanto NM, Bismark M. 2014. Keanekaragaman hayati flora dan fauna di kawasan hutan Pertamina Bukit Datuk Dumai, Propinsi Riau. Jurnal Penelitian Hutan dan Konservasi Alam 11(1): 77-89.

Samsoedin I, Waryono T. 2015. Hutan Kota dan Keanekaragaman Jenis Pohon di Jabodetabek. Penerbit Yayasan Kehati, Jakarta.

Siregar CA, Heriyanto NM. 2010. Akumulasi biomassa karbon pada skenario hutan sekunder di Maribaya, Bogor, Jawa Barat. Jurnal Penelitian Hutan dan Konservasi Alam 8(3): 215-226.

Soegianto A. 1994. Ekologi kuantitatif. Penerbit Usaha Nasional, Surabaya.

Suarja J. 2012. Hutan kota akan dibangun di Semper Timur, Jakarta Utara. http://www.jakarta.go.id/ web/news/2012/02/hutan-kota-bakal-dibangundisempertimur. (diakses 15 Maret 2018).

Subarudi, Samsoedin. 2012. Kajian kebijakan hutan kota: studi kasus di Provinsi Daerah Khusus Ibukota Jakarta (DKI). Jurnal Analisis Kebijakan Kehutanan. 9(2): 144-153.

Wardani M, Heriyanto NM. 2015. Autekologi Damar Asam Shorea hopeifolia (F.Heim) Symington di Taman Nasional Bukit Barisan Selatan, Lampung. Buletin Plasma Nutfah 21(2):89-98.

Widhi SJK, Murti SH. 2014. Estimasi stok karbon hutan dengan memanfaatkan citra landsat 8 di Taman Nasional Tesso Nilo, Riau. Jurnal Bumi Indonesia 3(2): 1-11.

Yilmaz H, Irmak MA, Yilmaz S, Toy S. 2008. Species Diversity of Four Major Urban Forest Types Under Extreme Climate Conditions in Erzurum, Turkey. International Journal of Biodiversity Science and Management, 4: 154-163. DOI 10.3843/ Biodiv.4.3.

Yilmaz H, Irmak MA. 2004. Evaluation of plant material used in open green spaces of Erzurum city (Turkey). Journal of Ecology 13: 9-16. 
Lampiran 1. Jenis tumbuhan yang ditanam di Taman Kehati Bumi Patra, Indramayu, jumlah dan statusnya

\begin{tabular}{|c|c|c|c|c|c|c|}
\hline No. & Nama lokal & Nama botani & Suku & Jumlah & $\begin{array}{l}\text { Status/ } \\
\text { kategori }\end{array}$ & Keterangan \\
\hline 1 & Manoa & Annona reticulata $\mathrm{L}$. & Annonaceae & 22 & & introduksi \\
\hline 2 & Buni & Antidesma bunius (L.) Spreng & Phyllanthaceae & 29 & & lokal \\
\hline 3 & Benda & Artocarpus elasticus Reinw. Ex BI. & Moraceae & 15 & & lokal \\
\hline 4 & $\begin{array}{l}\text { Belimbing } \\
\text { wuluh }\end{array}$ & Averrhoa bilimbi L. & Averrhoaceae & 7 & & lokal \\
\hline 5 & Nyamplung & Calophyllum inophyllum L & Clusiaceae & 25 & & lokal \\
\hline 6 & Bintangur & Calophyllum soulattri Burman f, Fl. & Clusiaceae & 29 & & lokal \\
\hline 7 & Kenari solo & Canarium asperum Benth. & Burseraceae & 21 & & introduksi \\
\hline 8 & Kenari & Canarium indicum L. & Burseraceae & 5 & & introduksi \\
\hline 9 & Bintaro & Cerbera manghas $\mathrm{L}$. & Apocynaceae & 48 & & lokal \\
\hline 10 & Sawo Duren & Chrysophyllum cainito L. & Sapotaceae & 9 & & introduksi \\
\hline 11 & Namnam & Cynometra cauliflora $\mathrm{L}$. & Leguminoseae & 19 & langka & lokal \\
\hline 12 & Kupa Anjing & Cynometra ramiflora $\mathrm{L}$. & Leguminoseae & 8 & & introduksi \\
\hline 13 & Bisbul & Diospyros blancoi A.DC. & Ebenaceae & 12 & & lokal \\
\hline 14 & Eboni & Diospyros celebica Bakh & Ebenaceae & 19 & & introduksi \\
\hline 15 & Culiket & Diospyros malabarica (Desr.) Kostel & Ebenaceae & 10 & & introduksi \\
\hline 16 & Rukem & Flacourtia rukam Zoll. \& Mor. & Flacourtiaceae & 21 & & lokal \\
\hline 17 & Mundu & Garcinia dulcis (Roxb.) Kurtz & Clusiaceae & 12 & & introduksi \\
\hline 18 & Merawan & Hopea odorata Roxb. & Dipterocarpaceae & 10 & & introduksi \\
\hline 19 & Gayam & $\begin{array}{l}\text { Inocarpus fagifer (Parkinson \& } \\
\text { Zollinger) Fosberg }\end{array}$ & Fabaceae & 17 & langka & lokal \\
\hline 20 & Merbau & Intsia bijuga (Colebr) O. Kuntze & Fabaceae & 10 & & introduksi \\
\hline 21 & Mangga & Mangifera indica $\mathrm{L}$. & Anacardiaceae & 1311 & & lokal \\
\hline 22 & $\begin{array}{l}\text { Sawo } \\
\text { Manila }\end{array}$ & Manilkara achras (Mill.) Fosberg & Sapotaceae & 6 & & lokal \\
\hline 23 & Kepayang & Pangium edule Reinw. & Achariaceae & 15 & langka & lokal \\
\hline 24 & Cereme & Phyllanthus acidus (L.) Skeels & Phyllantaceae & 9 & & introduksi \\
\hline 25 & $\begin{array}{l}\text { Glodokan } \\
\text { Tiang }\end{array}$ & $\begin{array}{l}\text { Polyalthia longifolia (Sonn.) } \\
\text { Thwaites }\end{array}$ & Annonaceae & 7 & & introduksi \\
\hline 26 & Matoa & $\begin{array}{l}\text { Pometia pinnata J.R. Forst. \& G. } \\
\text { Forst }\end{array}$ & Sapindaceae & 20 & & introduksi \\
\hline 27 & Campole & Pouteria camphechiana H.B \& K. & Sapotaceae & 5 & & introduksi \\
\hline 28 & Angsana & Pterocarpus indicus Willd & Fabaceae & 26 & & lokal \\
\hline 29 & Kecapi & $\begin{array}{l}\text { Sandoricum koetjape (Burm.F.) } \\
\text { Merr. }\end{array}$ & Meliaceae & 8 & & lokal \\
\hline 30 & Kesambi & Schleichera oleosa (Lour.) Oken & Sapindaceae & 28 & & lokal \\
\hline 31 & $\begin{array}{l}\text { Meranti } \\
\text { hitam }\end{array}$ & Shorea guiso (Blanco) BI. & Dipterocarpaceae & 20 & & introduksi \\
\hline 32 & Tengkawang & Shorea pinanga Scheff & Dipterocarpaceae & 8 & & introduksi \\
\hline 33 & $\begin{array}{l}\text { Meranti } \\
\text { Bapa }\end{array}$ & Shorea selanica (DC.) BI. & Dipterocarpaceae & 5 & & introduksi \\
\hline 34 & Kepel & $\begin{array}{l}\text { Stelechocarpus burahol Hook. F. \& } \\
\text { Thomson }\end{array}$ & Annonaceae & 8 & langka & lokal \\
\hline 35 & Kepuh & Sterculia foetida $\mathrm{L}$. & Malvaceae & 35 & & lokal \\
\hline 36 & Duwet & Syzygium cumini L. & Myrtaceae & 8 & & introduksi \\
\hline 37 & Kupa/Gowok & $\begin{array}{l}\text { Syzygium polycephaloides (C.B.Rob.) } \\
\text { Merr. }\end{array}$ & Myrtaceae & 12 & langka & lokal \\
\hline 38 & Resak Rawa & Vatica pauciflora BI. & Dipterocarpaceae & 10 & & introduksi \\
\hline
\end{tabular}

